\title{
SUSTAINABLE ENERGY: PRODUCER GAS AS AN ENERGY RESOURCE
}

\author{
Rahul Basu \\ Professor, Sambhram Institute of Technology, MS Palya, Jalahalli (E), Bangalore - 560097 \\ Email:ra4499@gmail.com
}

\begin{abstract}
Global warming and pollution due to Carbon emissions is an immediate worldwide concern. Fossil fuels continue to be a prime source for third world countries. Large Industrialised nations continue to pour pollution into the environment with impunity, expecting $\mathrm{CO} 2$ absorption by the forested underdeveloped nations. Replacement of fossil fuels by other carbon neutral and carbon negative technologies is now imperative at a global level. In this regard, Producer gas is proposed as an alternative energy cource. Biogas obtained by bacterial action on waster matter, results in high $N$ and $C$ sludge content after methane production. This sludge can be processed to give Producer Gas. Other crop waste like coconut husk, agricultural wastes and cellulosic wastes could be used directly. The slow reaction times of biogas (methane) production by bacterial action is avoided. The Producer gas can be stored or used directly as a substitute for methane which has hazardous qualities. In the earlyhalf of the 20th century it was piped directly to homes for cooking. Producer or Water gas was a petrol substitute in times of scarcity.
\end{abstract}

Keywords: Biogas, Pollution, Global Warming, Sustainable Energy, (EKC) Kuznets Curve, Carbon Credits, Carbon Footprint

\section{INTRODUCTION}

Natural sources of power have been used for centuries, and the use of wind, solar heating and drying and hydropower have been commonplace in many countries for centuries. It is only in the past decade or two that the global concern has mounted with concerns for the global environment and the future of the planet, with visible effects on the atmosphere and effects on climate worldwide. An example is the shrinking of glaciers worldwide, the shrinking of the polar icecaps and rising sea levels, resulting in worldwide calamities like Tsunamis, earthquakes and cyclones. These considerations and aspects have been incorporated into the national plans of many countries, and Global organizations and NGO's have also got into the picture. It is now common to talk about Carbon Credits and monetary equivalents that can be traded and used to offset production of pollutants by nations.

According to a recent study ( Scientific American Nov 13 2012), CO2 increase due to deforestation accounts for more CO2 than all vehicles worldwide. 4 wheelers produce $14 \%$ of the global carbon emissions, while upward of $15 \%$ is from deforestation. According to the EDF (Environmental Defence Fund), 32 million tons of tropical rain forests were cut down each year from 2000-2009. Forest clearing will put another 200 billion tons of Carbon Monoxide in the air in coming decades.

A major power source for underdeveloped and developing countries is from Natural organic fuels. Biomass continues as a source of cheap and polluting energy in rural areas, especially for below poverty line populations. The scarcity of urban dwelling spaces also forces many people to occupy fringe forest areas or collect biomass illegally from forests and destroy green cover in urban spaces. On the other hand, many people migrate to the large urban centres hoping to find work, occupying slums. The strain on the civic amenities due to the extra settlements on pavements and established slums causes problems like power outages, water shortage and epidemics. The problem of urban waste management is a difficult one. In addition, as it is now noticed, air pollution in the form of carbon emissions and methane cause global warming by the GreenHouse effect.

Profits from timber, charcoal, pasture and cropland induce people to cut down forests because of easy availability and low cost. The UNREDD programme provides incentives to people who care for forests and manage sustainably while still being able to benefit economically through a system of pollution credits. Brazil embraced REDD and slowed deforestation $40 \%$ since 2008 and is on the way to $80 \%$ reduction by 2020. India is not a member, though Bangladeshm Nepal, SriLanka, Pakistan, Myanmar have joined. Brazil is a major player in the sustainable development field, having already introduced biofuels and ethyl alcohol as motor fuel.

Pollution figures for India indicate $3000 \mathrm{lb} /$ capita in 2007, China at $10500 \mathrm{lb} /$ capita, and US at $42500 \mathrm{lb}$ /capita. India has the worst air pollution record in the world due to the large number of two wheelers and retrofitted CNG kits causing $30 \%$ more methane emissions together with emission from coal burning power plants.

It is well known that poverty and the degradation of the environment are closely linked, hence improvement of living standards and natural resource management at the grass roots level is essential in any strategy to reclaim the environment. The poor rely heavily on natural resources. 
In addition, diversion of common lands used historically for other public projects and schemes deprives the poor of their common resources, forcing them to encroach on forest land. The dominant sources of pollution in India are dosmestic burning and two stroke emissions, ( De Laat, J Geophys Res, 2001 using INDOEX measurements) (2)..

2012 was to be the International Year of Sustainable Energy for All, according to the UN. The climate food agricultural linkage is emphasized in relation to fossil fuel inputs. For a country like India which has a sizeable rural population subsisting on agriculture and depending on livestock, Biogas has provided a viable source of energy and has been subsidized by various Governmental incentives and schemes. The problem underlying such efforts is the extreme poverty in which the majority of the rural populace lives. In fact, traditional village lifestyles dictate the use of cow dung for cooking with fire, smearing cowdung solution on the ground, placing cow dung cakes on the walls and so on. Till recently it was difficult to get people to use cow dung as a crop fertilizer, and the major fertilizer companies have made hay of this fact.

\section{Advantages of BIOGAS}

Biogas has certain desirable qualities with regard to the environment:

1. It is low cost and low tech

2. It requires low investment and capital

3. It uses waste products and does not require chemical additives

4. It produces a sludge which can be used further as a fertilizer

5. It can contribute to treatment of domestic and municipal wastes.

Most of the subsidies given by State and NGO's so far have been on Biogas, whereas Producer gas has been neglected in the resurgence of Renewable energy sources.

Apart from the payoffs in secondary energy generation (i.e., after Methane has been recovered from biomass by bacterial action), the remaining bio matter/biomass residue which consists of $\mathrm{C}$ and $\mathrm{N}$ with $\mathrm{H} 20$ is capable of further reduction into the so called "Producer Gas". A further advantage is in reducing the biologically active component which may consist of any harmful bacteria, mosquito larvae and viruses and other vectors into inert form. The resultant solid matter is highly concentrated with Nitrogeneous matter and thus suitable as fertilizer for agricultural usage. Although the initial biomatter which may be dung, composted material and waste food matter can be used and is frequently applied directly on the fields, the result of Producer gas reduction is more inert and as useful if not more suitable as a fertilizer. Besides, the decomposition of animal dung in the open after being applied as a surface additive for crops yields large amounts of methane and adds to the pollutants in the atmosphere, besides contributing to vector propagation like flies and mosquitoes.
In Ghana, W. Africa, one of the main reasons of development of biogas is to treat sewage which is largely untreated and run off into the bush outside the villages, in order to improve sanitation and reduce attendant risks of epidemics and diseases endemic to Africa,(3).

\section{INTERNATIONAL EFFORTS IN THE AREA OF RENEWABLE ENERGY}

It appears that serious work has been done in the island nations of the Indian and Pacific Oceans, like the Philippines and SriLanka, subsidised by the International agencies like UN. In Africa, countries like Ghana have taken up Biogas projects at a national level in their National Strategic planning. According to a recent survey (3), the focus in Ghana has shifted from energy to sanitation, with construction of bio-toilets. The aim is to treat human wastes to a level where they can be safely discharged into drains. The remaining sludge is used as fertilizer.

In the Philippines, GEMCOR had set up gasifiers using coconut shell charcoal, resulting in cheap gas at lower rates than from wood or biomass. Boats have been fitted with engines running on producer gas, (4).

A number of raw materials have been researched for Producer gas, including coconut, sugar cane bagasse, rice husks, corn cobs, coffee bean husks, peanut shells, cotton gin trash and stalks. The list could use organic trash, which has been reported in the recent issue of Scientific American, (5) (Dec 2010, p24). Indian cities with their large slums and attendant sanitation problems could take a leaf from these efforts initiated by India's neighbours.

During times of petrol scarcity as in the last world war, engines were developed to run on coal gas and gas from wood, which would be towed behind the vehicles.

A survey was done by the FAO in the 1970's and the results were published as a paper (6.)

Photovoltaic Energy has also been looked at in detail in the context of agricultural and rural development. The life cycle and quality factors for such sources have been estimated. (7)

A paraphrased excerpt is attached:

\section{Recommendations for Sustainable Agriculture and}

\section{Rural Development}

a package of recommendations with technical cooperation fro FAO and others is envisaged

\section{Policy and planning}

- synergies to be identified as and when PV applications are promoted simultaneously in various rural sectors may be built into policies and programmes;

Kyoto Protocol to be implenented in the plans 
Research and development

$\mathrm{R} \& \mathrm{D}$ into agricultural irrigation systems linked with PV power

\section{Finance}

banks allow for loans to PV systems as collateral, financing of investments in agriculture uses of PV would be ranked higher than Solar Home Systems because of generated income.

\section{Demonstration, implementation and marketing}

- PV applications like drip-irrigation, cattle fences, water and aquaculture applications

PV systems for cottage industry activities

$P V$ business incubator approaches, with common access to phone/fax/web; along with

PV applications for basic socialservices such as education and health care;

\section{Training ;}

academic curricula at and educational programmes are to be prepared at all levels.

\section{f)Institutions}

$\square$ Infrastructural basis behind SARD to be activated by the institutions dealing

with PV systems.

Let us now look at one of the major alternative energy sources for Fossil fuel substitution:

\section{PRIMARY REACTIONS AND PRODUCTS FROM BIOMASS GASIFICATION:}

The gaseous products from carbon biomass are $\mathrm{CO}, \mathrm{CO}_{2}$, $\mathrm{H}_{2}, \mathrm{CH}_{4}, \mathrm{~N}_{2}$, water. Trace amounts of higher hydrocarbons are present also.

The reactions involve the steam reaction on carbon with limited oxygen:

$4 \mathrm{C}+2 \mathrm{H}_{2}+2 \mathrm{O}_{2}--\rightarrow 4 \mathrm{CO}+4 \mathrm{H}+\mathrm{O}_{2}$

$2 \mathrm{CO}+\mathrm{O}_{2----} \rightarrow 2 \mathrm{CO}_{2}$

Also there are sub reactions of $\mathrm{C}$ with $\mathrm{H}, \mathrm{H} 2$ and $\mathrm{H}_{2}$, similarly with $\mathrm{CO}$ and $\mathrm{H}$.

These reactions need the addition of heat which is supplied by burning additional raw material, and a supply of steam.

USE IN IC ENGINES: As a result of the impending shortage in worldwide fossil fuel supplies which include petrol and diesel, increasing efforts have been made to look at alternatives to the IC engine which has so far not been modified beyond the basic piston-cylinder-valve design (4 stroke and 2 stroke variants). Strong interests in the Petroleum and automotive industry has resisted and thwarted attempts to develop alternative designs and implementation of these in Industry. One can see this in viewing the basic undergraduate syllabi for Engineering colleges which still use books written before the 1970's, whilst books on steam turbines and gas turbines are also rewritten from outdated foreign texts.

Modification of engines to use Producer gas is not difficult, provided one understands the nature of the combustion and power cycle in the IC engine. Basically, one cannot run the engine at a speed beyond the rate at which the fuel gas ignites and burns (flame velocity). In addition, the compression and air/fuel ratio are important. If too high a compression results, there is possibility of the gas igniting spontaneously, (knocking), which would damage the engine. Producer gas is capable of higher Octane numbers than petrol, (OCTANE number being a measure of the compression ratio at which detonation occurs). As a result, higher engine thermal efficiencies can be achieved with Producer gas. Further refinements are possible but may need more research for Indian scenarios.

\section{PRODUCER GAS FOR POWER GENERATION:}

$1 \mathrm{~kg}$ air-dry wood (15-20\% mc) gives about 2.3 cub.meters of gas

1 litre petrol $=2.5$ to $3 \mathrm{~kg}$ wood

1 litre diesel $=3$ to $3.5 \mathrm{~kg}$ wood

$1 \mathrm{kWh}$ requires 1 to $1.3 \mathrm{~kg}$ charcoal, 2 to $4 \mathrm{~kg}$ woodchips or 2.4 to $3.2 \mathrm{~kg}$ rice husk.

Feasibility and viability of a gasifier project depends on many factors, including cost of fuel, labour costs, money and finance, design life, value of the energy produced, cost of disposal of the residue, and value of the sludge for fertiliser. Further benefits are there when the electricity if generated can be sold to the grid.

The existence of a national energy programme and incorporation of such schemes into the development plans at state and national level would enhance such energy schemes.

At present the focus has been blurred by the large corporations battling it out for offshore oil rights, trying to sell cheap gas guzzling cars to the public, the conflicts (oil generated) in the middle east, and other political agendas.

The attendant benefits of health and sanitation have been almost ignored in the energy plans at the higher levels.

In Tanzania, a programme for design of gasifiers for maize mills in rural areas was taken up by the Small Industries Development Organisation and the Nederlands Twente University, (8). A similar system was developed at Chulalongkorn University in Thailand. In El Salvador, with GEKA of Karlsruhe, coffee bean husks are burnt and the gas mixture fed to further dry coffee beans. In Valdosta, Georgia and Auburn, Alabama peanut shells have been used to give heat for drying. In Asia, rice husks are very commonly available as a byproduct, but according to the 
FAO in 1975, no mill existed which used steam produced by husk fired boilers. India and Thailand directly used rice husks as a form of boiler heat fuel, with some other countries also following suit. Parboiled rice in India is made mostly (50\% usage) by husk fired boilers, with some mills in Sri Lanka, Guyana, and Italy doing the same. The Govt of Malaysia had given funds for development of two pilot plants at rice mills using one ton of rice husks per hour. Electric power output of about $350 \mathrm{KW} /$ hour has been obtained in $1983(9,10)$.

\section{Drawbacks of Producer and SYN Gas}

Many i.c. engines and gas turbines being used for power generation are now using syngas and producer gas. It appears that while natural gas has 3\% water content, syn gas has about $18 \%$ water content which creates degradation and corrosion problems in the metal parts of these engines, (18)

\section{Overall Efficiency and Economic Analysis of the}

\section{Scheme:}

Since Producer gas production requires heat and steam production as input, there is an expenditure of energy involved which debits from the overall total of energy. The heating can be obtained by diverting part of the biogas obtained in the primary digestion stage to be used for heating and producing steam and high temperatures in gasifying the sludge residue for Producer gas. Alternatively, dried biomass used for the initial biogas production could be ignited and used for the secondary producer gas stage. So far no study has been done on the efficiency and economics of the scheme.

\section{FUTURE STUDIES AND AVENUES OF RESEARCH:}

It may be possible to invoke the genetic modification of microbes to directly excrete hydrocarbons. Turning water, photonic energy and Carbon dioxide into hydrocarbons is a very old process developed by Nature, which uses chlorophyll. Perhaps more useful than solid carbohydrates, would be a liquid hydrocarbon that could directly be put to use as fuel. Algae are known to efficiently convert Carbon dioxide into fatty acids, and similarly potato plants into carbohydrates. Converting this potato starch into alcohol is a long and expensive process. There has been a search for micro organisms that could do this, (11). Alternatively, sugars can be turned into alcohol, but again there are attendant costs. Much more attractive and useful would be a way to convert raw materials directly into hydrocarbon fuels. Apart from micro organisms, mobile robots are being proposed that would "eat" garbage and unwanted plants and convert these into hydrocarbon fuel forms, (12).

The direct conversion of cellulose to alcohol (cellulolysis) using lignocellulose (wood cellulose containing lignin a component of wood), has been researched at Argonne Labs (13). The process depends on cellulase enzymes produced by bacteria. Saccaromyces cerevisiae, Zymomonas mobilis,
E Coli., are some bacteria targeted for bio engineering to produce ethanol via the cellulosis route.

Producer gas has been applied as a raw material for bacterial conversion to ethanol also, using the bacteria Clostridium Ljungdahlii, which ingests $\mathrm{CO}, \mathrm{CO} 2$ and $\mathrm{H}_{2}$ producing Ethanol and water. This process involves Gasification, fermentation and distillation to yield alcohol. The alternative is to use a catalytic reactor. (Catalysis involves intermediate compounds that get involved in the reaction but are unchanged in composition at the end).

The physical and chemical parameters affecting fermentation of cellulose has been studied by various groups $(14,15)$. Another bacteria acetivibro celluloyticus produces acetate, ethanol, water and carbon dioxide.

Recently, groups have tried to bioengineer bacteria to give oil for fuel directly. The group LS9 with UC Berkeley has engineered a bacterium to make enzymes to convert biomass into diesel oil, (16). A recent patent 7794969 uses cyanobacteria to produce n-alkanes, (17).

The end is not in sight, and clearly microorganisms exist or can be modified to excrete oils which can be used as fuels, possible without further processing. However the overall effect on the effect on life on the planet and the ecology and environment must be carefully evaluated before attempting such bioengineering on a large scale in order to satiate the need of some industrial groups which have stuck to old designs for motive engines. The alternative would be to invest in alternative designs for motive power converters.

The I.C. engine was a byproduct of the Industrial revolution and the industrialisation of the Midwest USA, with resultant mass migrations, prior to which electric cars, steam cars and other variants were in vogue in the early $20^{\text {th }}$ century. In fact the steam engine served Indian railroads for well over a century before the diesel

engines took over. Hence one must not get carried away by the demons of Science and Finance and attempt to change the natural order of nature and life by introducing artificial genetic alterations.

In order to maintain sustainable development in consonance with International efforts and agreed norms, it is essential that efforts to reengineer life forms, regardless of good motives be examined carefully as there can be repercussions in the long run.

In conclusion I refer to an ongoing debate amongst various International Pundits about the Pros and Cons of a relationship between Economic Growth and Environmental Pollution and Quality. I refer to two references emanating from MIT and World Bank experts. It was suggested in a nutshell, that economic growth alone would take care of the environment after a certain level of prosperity was reached. The idea is a fall out of the EKC (Environmental Kuznets Curve) . It is also recognized that depletion of resources from LDC's is an important effect because it is rare for 
natural resources and capital obtained in this way by pirating resources of LDC's by More Developed countries to be reinvested in a sustainable way,(19,20). It is perhaps one reason why the developed countries refuse to sign the Kyoto and other protocols, believing that Nature will eventually take care of itself.

\section{REFERENCES:}

[1] Scientific American Nov 132012

[2] ATJ De LaatJ deGouw, J LeLieveld, A Hansel, , J Geophys Res., V106,22,ppp469-480, Nov 27, 2001

[3] 3. E.C. Bensah and A. Brew-Hammond, "Biogas Effluent and Food Production in Ghana", $4^{\text {th }}$ National Conference of Ghana Society of Agricultural Engineering, March14th 2008.

[4] 4. D.B.Mahin, "Bioenergy from Crop residues", BST, Office of energy, Wash DC, 1983.

[5] Scientific American, V5,No12, p24, Dec 2010

[6] FAO forestry paper,"Wood gas as Engine Fuel", ISBN 9251024367, 1972

[7] FAO working paper 2, "Solar PV energy for sustainable Agricultural and Power Development", FAO, Rome , 2000

[8] see ref (2), p9

[9] see $\operatorname{ref}(2), \mathrm{p} 11$

[10] see $\operatorname{ref}(2), \mathrm{p} 13$

[11] en.wikipedia.org/wiki/ethanol_fermentation

[12] 12 Scientific American, V5,No12,p 21, Dec 2010

[13] www1.eere.energy.gov/biomass/news.html

[14] V.SenthilKumar and P Gunasekharan, J..of Sci and Ind.Res., V64,Nov 2005,p845-853

[15]D.W.Armstrong and S.M.Martin, "Bacterial fermentation of cellulose: Effect of physical and chemical parameters", Biotechnology and Bioengineering, V25,11, pp2567-2575,Nov 1983.

[16] technologyreview.com/energy/24422

[17] N.B.Reppas and C.P.Perry, US Patent 7794969, US Patent Sept 142010

[18] 18 MBasu Majumder and R Clayton, presented at $42^{\text {nd }}$ ICMCTF, San Diego , 2015

[19] Grossman G M and Krueger A B ,m "Environmental Impacts of a North American Free Trade Agreement", in Garber $\mathrm{P}(\mathrm{Ed})$, The $\mathrm{U} \mathrm{S}$ Mexico Free Trade Agreement, Cambridge Press, MIT, 1993

[20]20.Barbier EB, Introduction to the Environmental Kuznets curve Special ISSUE, Environmental and Developmental Economics 2, (1997) p 369-381. 